\title{
DAMPAK SISTEM KEGIATAN BELAJAR MENGAJAR (KBM) DARING AKIBAT COVID-19 TERHADAP SISWA
}

\author{
Gurita Arum Sari ${ }^{1}$ \\ ${ }^{1}$ SMK Negeri 1 Panji Situbondo \\ Email: thaniacleona@gmail.com
}

Received: Sept 14, $2020 \quad$ Revised: Sept 17, $2020 \quad$ Accepted: Sept 21, 2020

\begin{abstract}
ABSTRAK
Sehubungan dengan pandemi covid-19, Menteri pendidikan menerbitkan surat edaran (SE) No. 3 tahun 2020 mengenai pencegahan penyebaran dan penularan covid-19 di instansi pendidikan menyatakan bahwa sekolah dan perguruan tinggi diliburkan. Proses Kegiatan Belajar Mengajar (KBM) dilaksanalan di rumah secara daring. Tujuan penulisan artikel ini untuk mengetahui dampak sistem kegiatan belajar mengajar (KBM) daring akibat Covid-19 terhadap siswa. Beberapa dampak positif KBM daring bagi siswa antara lain siswa dapat menambah nilai kemandirian dan pendewasaan individu, meningkatnya kemandirian siswa, siswa hidup bersih dan sehat, siswa sering dan senang membantu orangtua dan mempunyai keterampilan lebih untuk belajar keterampilan hidup misalnya memasak, cuci baju, dan lain sebagainya. Dampak negatif bagi para siswa antara lain materi yang diperoleh siswa hanya sedikit, sebagian besar siswa tidak memahami mata pelajaran yang disampaikan melalui daring, pendidikan karakter siswa selama masa pandemi sedikit terabaikan, kurang efektif bagi para siswa, dan partisipasi siswa pada saat pembelajaran online berkurang.
\end{abstract}

Kata kunci: Covid-19, Sistem KBM Daring, Dampak Positif, Dampak Negatif .

\begin{abstract}
Due tue Covid-19 pandemic, the Minister of Education issued a letter Circular (SE) No. 3 of 2020 concerning the prevention of the spread and transmission of covid-19 in educational institutions states that schools and colleges are closed. The process of Teaching and Learning Activities (KBM) is carried out at home online. The purpose of writing this article is to determine the impact of the online teaching and learning activity (KBM) system due to Covid-19 on students. Some of the positive impacts of online teaching and learning for students include students being able to add value to individual independence and maturity, increase student independence, students live clean and healthy lives, students often and enjoy helping their parents and have more skills to learn life skills such as cooking, washing clothes, and so on. so. The negative impacts for students include only a little material obtained by students, most students do not understand subjects delivered online, student character education during the pandemic is a little neglected, less effective for students, and student participation during online learning is reduced.
\end{abstract}

Keywords: Covid-19, Online Teaching and Learning System, Positive Impact, Negative Impact 


\section{PENDAHULUAN}

Covid-19 atau coronavirus disease-2019 adalah peyakit infeksi yang baru ditemukan pada manusia dan belum diidentifikasi sebelumnya. Keluhan yang ditimbulkan biasanya adalah gangguan pada saluran pernapasan yang akut seperti batuk, demam, dan dada terasa sesak. Rata-rata waktu inkubasi virus ini adalah 5-6 hari dan waktu inkubasi terpanjang adalah 2 minggu. WHO telah mengumumkan covid-19 sebagai kegawatdaruratan dalam dunia kesehatan sejak 30 januari 2020. Dunia telah diresahkan oleh kegawatdaruratan pandemi covid-19. Sejumlah 2 kasus terkonfirmasi covid-19 dilaporkan pertama di Indonesia pada 2 maret 2020.

Setiap hari terjadi peningkatan kasus hingga mencapi 10 kasus terkonfirmasi covid-19 pada 16 aret 2020 (Yurianto, 2020). Selama 2 minggu terjadi penambahan kasus dan kenaikan tingkat kematian yang sangat signifikan yaitu sebanyak 1528 kasus dan 136 kasus kematian. Prosentase kematian akibat covid-19 di Indonesia mencapai 8,9\%, tingkat kematian di Indonesia adalah tingkat kematian paling tinggi di Asia Tenggara. Adanya kasus covid-19 caat ini sangat berdampak bagi semua sektor dan seluruh masyarakat. Sektor yang terdampak oleh Covid-19 antara lain social, ekonomi, pariwisata, dan pendidikan (Susilo, 2020).

Bidang pendidikan merupakan salah satu bidang yang terdampak oleh covid-19. Akibat adanya covid-19 pemerintah mengeluarkan surat edaran (SE) pada 18 maret 2020 tentang semua kegiatan baik diluar atau didalam ruang di semua bidang sementara waktu ditunda untuk mengurangi penularan covid-19. Salah satunya penyebaran dan penularan di lembaga pendidikan (Dewi, 2020). Menteri pendidikan juga menerbitkan surat edaran (SE) No.3 tahun 2020 mengenai pencegahan penyebaran dan penularan covid-19 di instansi pendidikan menyatakan bahwa sekolah dan perguruan tinggi diliburkan sampai kondisi yang memungkinkan atau aman (Kemdikbud, 2020).

Hal tersebut dilakukan guna memutus penyebaran dan penularan covid-19. Selanjutnya kegiatan belajar mengajar dilakukan secara online untuk semua tingkat pendidikan (Pratiwi, 2020). Saat ini proses belajar mengajar masih berpedoman pada surat edaran (SE) Mendikbud No.4 tahun 2020 yang didukung surat edaran (SE) Mendikbud No.15 tahun 2020 mengenai pedoman pelaksanaan pembelajaran jarak jauh selama pandemi covid19. Surat edaran mendikbud menjelaskan bahwa penerapan pembelajaran jarak jauh dilakukan untuk memenuhi hak siswa dalam memperoleh layanan pendidikan saat masa pandemi covid-19, mencegah penyebaran dan penularan covid-19 di instansi pendidikan, melindungi seluruh satuan pendidikan dari efek negatif covid-19, dan memenuhi dukungan psikososial bagi guru, siswa, dan orangtua 
(Kemdikbud, 2020).

Proses pembelajaran online dilaksanakan melalui daring atau jarak jauh (Pratiwi, 2020). KBM Daring merupakan proses pembelajaran yang memanfaatkan jaringan internet. Kegiatan pembelajaran online ini dilakukan untuk mengganti kegiatan pembelajaran secara langsung. Dengan pembelajaran secara daring para siswa memiliki waktu yang cukup banyak untuk belajar, dapat melakukan pembelajaran dimanapun dan kapanpun dapat menggunakan berbagai macam aplikasi seperti zoom, classroom, livechat, whatsapp grop, video converence, ataupun telepon untuk berinteraksi dengan guru. Pembelajaran online merupakan inovasi dalam dunia pendidikan untuk menyelesaikan tantangan yang ada di dunia pendidikan yaitu keterbatasan sumber belajar yang inovatif (Nakayama dan Yamamoto, 2007). Metode pembelajaran jarak jauh yang diniliai efektif bagi para siswa adalah dengan memberikan tugas secara online untuk siswa melalui zoom, classroom, atau whatsapp group, metode ini dinilai efektif dilakukan dalam keadaan darurat akibat adanya pandemi covid-19 seperti sekarang ini.

Para guru menggunakan metode yang beragam, dari perbedaan metode belajar tersebut dasarnya tetap sama yaitu dilakukan melalui daring atau jarak jauh. Ada guru yang menggunakan metode mengajar dikelas dan dividiokan kemudian video dikirim ke whatsapp grup, menggunakan vidio call bersama, ada yang memanfaatkan konten gratis yang tersedia di berbagai sumber (Ashari, 2020). Waryanto (2006) mengatakan bahwa "KBM daring mempunyai berbagai kelemahan yaitu membutuhkan infrastuktur yang memadai untuk mengakses jaringan internet, biaya relatif mahal, dan berbagai kendala lain yang menyebabkan komunikasi melalui internet menjadi lamban". Pembelajaran online akan menjadi lebih efektif apabila siswa aktif/ terdapat interaksi aktif antara siswa dan pengajar sehingga tujuan pembelajarandapat tercapai (Wicaksono, 2012).

Keberhasilan suatu media pembelajaran ataupun metode pembelajaran tergantung dari karakter masing-masing siswa. Tidak semua siswa akan berhasil dalam pembelajaran daring. Hal ini dipengaruhi oleh beberapa faktor diantaranya adalah faktor lingkungan siswa saat belajar dan karakter dari siswa tersebut (Nakayama dan Yamamoto, 2007).

Selain mempunyai kelemahan dan kelebihan, KBM daring juga mempunyai banyak dampak negatif dan dampak positif terhadap para siswa. Dampak positif KBM daring bagi siswa antara lain siswa dapat menambah nilai kemandirian.

\section{HASIL DAN PEMBAHASAN}

Corona merupakan nama salah satu virus yang bisa menginfeksi manusia. Pada manusia, virus ini dapat mengganggu sistem pernapasan seperti infeksi pada sistem 
pernapasan, flu biasa, hingga penyakit serius lainnya. Terdapat dua macam coronavirus yang dapat mengakibatkan penyakit sehingga timbul gejala berat. MERS dan SARS merupakan penyakit yang diakibatkan oleh coronavirus. SARS-Cov-2 merupakan salah satu jenis baru dari coronavirus yang ditemukan pada akhir tahun 2019 di Wuhan Cina (Kemenkes, 2020). Sistem pernapasan manusia yang diserang oleh SARS-Cov-2, sehingga mengakibatkan gangguan ringan pada saluran parnapasan, infeksi pada paru-paru, hingga mengakibatkan kematian. Virus ini dapat menyerang berbagai usia seperti anak-anak, dewasa, lanjut uasia, ibu hamil dan menyusui (Fadli, 2020).

Transmisi SARS-CoV-2 bisa terjadi melalui kontak tidak langsung, atau kontak langsung apabila kontak erat dengan pasien terkonfirmasi covid-19. Penyebaran dan penularan dapat terjadi melalui sekresi air liur, dan droplet saluran pernapasan yang dikeluarkan pada saat orang yang terkonfirmasi covid-19 melakukan bersin, batuk, atau berbicara.

Transmisi SARS-CoV-2 terjadi pada saat seseorang berada dalam jarak 1 meter (kontak erat) dengan orang yang positif terinfeksi virus tersebut dan menunjukkan gejala yang dialami yaitu batuk atau bersin, dalam kondisi seperti ini droplet yang mengandung virus tersebut dapat mencapai hidung, mata atau mulut orang yang berada di sekitarnya dan dapat menimbulkan infeksi. Penyakit yang disebabkan oleh virus ini disebut covid-19 (WHO, 2020)

Covid-19 atau Coronavirus Diseases 2019 adalah sebuah nama yang baru saja diberikan oleh WHO terhadap pasien dengan infeksi SARS-Cov-2 yang ditemukan di kota wuhan untuk pertama kalinya. Ditemukan pertama kali pada akhir tahun 2019 yang penyebarannya terjadi sangat cepat dan menyebabkan kejadian luara biasa yaitu pandemi covid-19 (Handayani dkk, 2020). Covid-19 adalah sebuah nama yang baru ditemukan pada manusia dan belum pernah diidentifikasi sebelumnya. Keluhan yang ditimbulkan biasanya adalah gangguan pada saluran pernapasan yang akut seperti batuk, demam, dan dada terasa sesak. Rata-rata waktu inkubasi virus ini adalah 5-6 hari dan waktu inkubasi terpanjang adalah 2 minggu (Yurianto dkk, 2020)

Proses pembelajaran KBM dilaksanakan di rumah masing-masing dengan metode pembelajaran online atau daring (Pratiwi, 2020). KBM daring merupakan proses pembelajara yang memanfaatkan jaringan internet. KBM daring ini dilaksanakan guna mengganti KBM konvensional. Dengan KBM secara daring para siswa memiliki waktuyang cukup banyak untuk belajar,dapat melakukan pembelajaran dimanapun dankapanpun. Siswa dapat menggunakan berbagai macam aplikasi seperti zoom, classroom, livechat, whatsapp grop, video converence, ataupun telepon untuk berinteraksi dengan guru. 
Pembelajaran online merupakan inovasi dalam dunia pendidikan untuk menyelesaikan masalah akan keterbatasan sumber belajar yang inovatif (Nakayama dan Yamamoto, 2020).

Sekolah yang belum menerapkan kegiatan belajar mengajar jarak jauh bisa mengembangkan kreatifitas yang dimiliki guru untuk memaksimalkan metode belajar alternatif selama masa pandemi. Para guru bisa memanfaatkan sumber media yang sudah tersedia seperti buku yang diberikan oleh sekolah dengan jadwal yang sudah ditetapkan (Dewi, 2020). Metode KBM jarak jauh yang dinilai efektif bagi para siswa adalah dengan memberikan tugas dan mengumpulkan tugas secara online kepada siswa melalui sosmed atau aplikasi. Metode ini dinilai efektif dilakukan pada keadaan pandemi covid-19 ini. Para guru menggunakan metode yang berbeda-beda, dari perbedaan cara mengajar tersebut dasarnya tetap sama yaitu dilakukan secara online. Bisa menggunakan metode mengajar dikelas dan dividio kemudian dikirimkan ke whatsapp group atau aplikasi lainnya, atau menggunakan metode vidio call bersama, ada yang memanfaatkan konten gratis yang tersedia di berbagai sumber (Ashari, 2020).

Terdapat 2 efek bagi kelangsungan pembelajaran yang diakibatkan covid-19. Pertama adalah untuk jangka pendek dan jangka panjang. Efek jangka pendek dan jangka panjang. Sebagian besar keluarga di Indonesia kurang mengerti dengan kegiatan belajar dirumah. Sekolah atau belajar dirumah bagi sebagian besar keluarga di Indonesia adalah sesuatu yang baru. Khususnya untuk orangtua yang bekerja dan tidak dirumah.

Kemudian mengenai masalah psikologis siswa yang sudah biasa bertatap muka dengan dengan guru, akan susah membiasakan diri untuk melakukan pembelajaran online. Pelaksanaan pembelajaran dilakukan secara daring. Pembelajara daring berlangsung dengan skala yang tidak terukur dan belum teruji karena tidakpernah terjadi. Didesa terpencil yang sangat padat dan sebagian besar berusia sekolah menjadi kebingungan, karena infrastruktur teknologi informasi sangat kurang. Pemberian nilai kepada siswa berlangsung secara daring dan banyak kesalahan karena sistem yang dipakai tidak memiliki standart. Sehingga banyak penilaian yang tidak sesuai standart (Aji, 2020).

Secara formal KBM konvensional dapat digantikan KBM daring, namun pembelajaran karakter selama kondisi sekarang akan sedikit berkurang. Pada saat KBM konvensional, pembelajaran karakter dapat dilaksanakan secara langsung dan diawasi oleh guru. Akan tetapi saat KBM daring hanya terdapat trasferpengetahuan saja. Tidak ada yang menjamin para siswa melakukan pembelajaran karakter dari orangtua masing-masing sesuai standart sekolah (Unissula, 2020).

Di sekolah, penguatan pendidikan karakter ini telah dilakukan dengan baik yaitu dengan menyelipkan nilai-nilai karakter ini pada setiap aktivitas pembelajaran (Dalyono \& 
Lestariningsih, 2016). Akan tetapi, hal ini tidak akan berjalan maksimal dikarenakan pendidikan karakter harus melibatkan semua aspek lingkungan secara garis besar yaitu keluarga, sekolah dan masyarakat (Supranoto, 2015). Pendidikan karakter di lingkungan keluarga merupakan pendidikan karakter terbaik yang bisa dilakukan. Namun, selama ini usaha optimalisasi pendidikan karakter di lingkungan keluarga ini kurang maksimal atau belum dikonsep dengan baik (Syarbini, 2014). Karena kurangnya kesadaran orang tua dalam pendidikan karakter untuk ananknya, [kesibukan orang tua, dan ketidaktahuan orang tua bagaimana cara membentuk karakter yang baik untuk anak (Muslikhin, 2019).

Materi yang diperoleh siswa lebih sedikit dan kurang dapat dipahami terutama pada mata pelajaran yang membutuhkan praktikum. Apalagi dengan banyaknya siswa menyebabkan kurang terkontrolnya pembelajaran dan pengawasan oleh guru. Hal tersebut juga disebabkan karena guru lebih fokus memberikan tugas ketimbang materi. Pelaksanaan KBM daring berjalan dengan lancar, namun dirasakan sebagian guru dan siswa kurang ideal dibandingkan KBM secara konvensional. Komunikasi yang terkadang dilakukan secara tidak serentak membuat sebagian siswa merasa kesulitan untuk mengajukan pertanyaan pada saat proses pembelajaran berlangsung. Komunikasi terjalin kurang lancar tersebut menyebabkan materi menjadi sulit dipahami. Selain itu, letak dan kondisi geografis tempat tinggal mahasiswa yang berbeda-beda terkadang membuat koneksi internet buruk sehingga mengganggu audio dan tampilan/visualisasi materi ajar pada layar laptop.

Selain itu, online melalui vidio call bersama, sehingga anak akan benar-benar belajar. Guru juga harus berkoordinasi dengan orangtua siswa, bisa menggunakan foto kegiatan saat dirumah. Harus dipastikan terdapat interaksi yang baik antara guru, siswa dan orangtua (Dewi, 2020).

KBM daring akan menjadi menjadi lebh efektif apabisla siswa aktif/terdapat interaksi aktif antara siswa dan pengajar sehingga tujuan pembelajaran dapat tercapai (Wicaksono, 2012). Keberhasilan suatu media pembelajaran ataupu metode pembelajaran tergantung dari karakter masing-masing siswa. Tidak semua siswa akan berhasil dalam proses KBM daring. Hal ini dipengaruhi oleh beberapa faktor diantaranya adalah faktor lingkungan siswa saat belajar dan karakter dari siswa tersebut (Nakayama dan Yamamoto, 2007).

Media merupakan semua yang dimanfaatkan untuk menyampaikan pesan dari pengirim pesan ke penerima pesan sehingga bisa merangsang pikiran, perasaan, dan perhatian. Pengetahuan tentang tenkonolgi informasi menjadi salah satu yang harus dipelajari siswa untuk bisa melakukan KBM daring. 
Pembelajaran online memang membutuhkan ketekunan pribadi, kemandirian, dan tanggung jawab diri sendiri, dikarenakan guru tidak bisa mengontrol secara langsung. Siswa memperoleh materi dengan cara mendowload file yang dikirim oleh guru, kemudian membaca materi tersebut, selanjutnya siswa harus menjawab soal dan mengumpulkan jawaban melalui aplikasi online. KBM daring akan menghasilkan peningkatan kinerja dibandingkan KBM konvensional. KBM daring juga dapat meningkatkan pengetahuan teknologi informasi, meningkatkan pendewasaan individu, dan dapatmenambah nilai kemandirian (Gustiana, 2020).

Meningkatnya pengetahuan siswa mengenai kesehatan seperti

cara cuci tangan yang benar, menggunakan masker ketika bepergian dan lain sebagainya. Menurut riset yang dilakukan oleh The Conversation, pembelajaran dengan metode daring masih belum berjalan ideal namun masih tetap menjadi cara yang paling efektif. Sebagian besar orangtua merasa bahwa anak-anak mereka mengalami perubahan yang baik. Dampak positif akibat kebijakan KBM daring ini adalah meningkatnya kemandirian siswa, siswa hidup bersih dan sehat, siswa sering dan senang membantu orangtua dan mempunyai keterampilan lebih untuk belajar keterampilan hidup misalnya memasak, cuci baju, dan lain sebagainya (The conversation).

\section{KESIMPULAN}

Dampak positif KBM daring bagi siswa antara lain siswa dapat menambah nilai kemandirian dan pendewasaan individu, siswa hidup bersih dan sehat, siswa mempunyai knowledge mengenai covid-19, siswa sering dan senang membantu orangtua. Dampak Negatif bagi para siswa antara lain materi yang diperoleh siswa hanya sedikit, sebagian besar siswa tidak memahami mata pelajaran yang disampaikan secara daring, pendidikan karakter siswa selama masa pandemic sedikit terabaikan, kurang efektif bagi para siswa.

\section{DAFTAR PUSTAKA}

Aji, Rizqon H,S, 2020. Dampak covid-19 pada pendidikan di indonesia sekolah, keterampilan, dan proses pembelajaran. Journal Sosial dan Budaya Syari. Vol.7 (5): 395-402.

Ashari, M. 2020. Proses pembelajaran daring di tengah antisipasi penyebaran virus corona dinilai belum maksimal. https://www.pikiran-rakyat.com/pendidikan/pr-01353818/prosespembejalaran-daring-di-tengah-antisipasi-penyebaran-virus-corona-dinilai-belum-maksimal 
Dalyono, B., dan Lestariningsih, E. D.2016. Implementasi penguatan pendidikan karakter di sekolah. Majalah Ilmiah Pengembangan Rekayasa Sosial dan Humaniora. Vol.3 (2): 33-42.

Dewi, Wahyu F.D. 2020. Dampak covid-19 terhadap implementasi pembelajaran daring di sekolah dasar. Journal Ilmu Pendidikan. Vol.2 (1): 55-61.

Fadli, Ari. 2020. Mengenal covid=19 dan cegah penyebarannya dengan "peduli lindungi" aplikasi berbasis android. Purwokerto: Teknik Elektro Unsoed.

Handayani, D., D. R. Hadi., F. Isbani-ah., E. Burhan., \& H. Agustin. 2020. Penyakit Virus Corona 2019. Jurnal Respiratori Indo.Volume 40 (2): 119-129.

Kementerian Kesehatan, 2020. Kesiapan Kemenkes dalam Menghadapi Outbreak Novel Coronavirus. Simposium Papdi 29 Januari 2020.

Kementerian Pendidikan dan Ke-budayaan. 2020. Surat edaran (SE) Mendikbud No.3 tahun 2020 tentang pencegahan covid-19 pada satuan pendidikan.

Kementerian Pendidikan dan Ke-budayaan. 2020. Surat edaran (SE) Mendikbud No.4 tahun 2020 tentang pelaksanaan kebijakan pendidikan dalam masa darurat

Nakayama, M dan Yamamoto, H. 2007

The impact of learner characteristics on learning performance in hybrid courses among japanesestudents. Elektronic Journal E-learnin. Vol.5(3)

Pratiwi, Erica, W. 2020. Dampak covid-19 terhadap kegiatan pembelajaran online disebuah perguruan tinggi kristen satya wacana. Perspektif Ilmu Pendidikan. Vol.34(1):1-8.

Rosali, Ely. 2020. Aktifitas pembela-jaran daring pada masa pandemi covid-19 di jurusan pendidikan geografi universitas siliwangi tasikmalaya. Geography Science Education Journal. Vol.1(1):21-30.

Supranoto, H. 2015. Implementasi pendidikan karakter bangsa dalam pembelajaran SMA. Jurnal Promosi. Vol.3(1): 36-49.

Susilo, A., G.M. Rumende., G.W.

Pitoyo., W. D. Santoso. 2020.

Coronavirus disease 2019: Tinjauan literatur terkini. Jurnal Penyakit Dalam Indonesia. Vol.7 (1): 45-67.

Syarbini, A. 2014. Model Pendidikan Karakter dalam Keluarga.Jakarta. PT. Elex Media Komputindo.

The Conversation. 2020. Riset dam-pak Covid-19: Potret Gap Akses Online "Belajar dari Rumah" dari 4 Provinsi. https://theconversation.com/riset-dampak-covid-19-potret-gap-aksesonline-belajar-dari-rumah-dari-4-provinsi-136534

Unissula. 2020. Dampak Pembelaja-ran Daring Di Masa Pandemi 
Bagi Pendidikan Karak-ter.http://unissula.ac.id/c24-berita-unissula/dampak-pembelajarandaring-di-masa-pandemi-bagi-pendidikan-karakter/

Waryanto, N. H. 2006. Online Learning Sebagai Salah Satu Inovasi Pembelajaran. Pythagoras: Jurnal Matematika dan Pendidikan. Volume 2(1): 10-23.

Yurianto, Ahmad, Bambang Wibowo,

K. P. 2020. Pedoman Pencegahan Dan Pengendalian Coronavirus Disease (Covid-19) (M. I. Listiana Azizah, Adistikah Aqmarina (ed.)

WHO. 2020. Transmisi SARS-CoV-2 Implikasi Untuk Kewaspadaan Pencegahan infeksi: Pernyataan keilmuan.

Wicaksono, S. R. 2012. Kajian Pembelajaran Online Berbasis Wiki Di Lingkup Perguruan Tinggi. Journal of Education and Learning (EduLearn) Volume 6(1): 51. 